\title{
УУРЫН ЗУУХАНД НУУРСНИЙ ШАТАЛТЫН ЯВЦАД АГААРТ ЯЛГАРАХ БОХИРДУУЛАГЧ ХИЙН СУДАЛГАА
}

\author{
Ч.Сономдагва ${ }^{1}$, Ш.Эрдэмиэиэг ${ }^{1}$ \\ ${ }^{1}$ ХШУИС-ийн ХУрээлэн буй орчин, Ойн инженерчлэлийн тэнхим \\ Монгол Улсын Их Сургууль, Монгол улс \\ Цахим шуудан: ch_sonomdagva@num.edu.mn
}

\section{ХУРААНГУЙ}

Улаанбаатар хотын гэр хорооллуудад байрлах, агаар бохирдуулагч эх ҮҮсвэрУүдийн нэг болох уурын зуухнуудын утаанаас ялгарах $\mathrm{CO}, \mathrm{SO}_{2}, \mathrm{NO}_{x^{\prime}}$ нарийн ширхэгт үнсний тоосонщор /НШҮТ/ гэсэн гол бохирдуулагчдыг хэмжсин харьиуулан судаллаа. Утааны ялгаралаас хамаарсан агаарын бохирдлыг тооиох бүх программын үндэс нь Гауссын тархалтын загвар байдаг. Энгийн Гауссын тархалтын загвар нь иэг дээр тулгуурладаг буюу тухайн яндан дээр тулгаарлан тооцдог. Гэхдээ ҮҮнийг шугаман эх Үүсвэр болон талбайн эх Үүсвэр болгон өөрчилж бас болно. Гауссын иэээн эх үүсвэрийн тархалт нь эх Үүсвэрийн хүчин чадал, салхины хурд, яндангийн өндөр, орчны нөхиөл зэргээс хамаарна.

Судалгаанд хамрагдсан нийт зуухны хүхэрлэг хийн агууламжаар 85\% нь их бага хэмжээгээр стандарт хэмжээнээс хэтэрсэн байгаа бөгөөд үүнээс $30 \%$ нь стандарт хэмжээнээс 1.8-2.1 дахин хэтэрсэн байна. ЭнэхүY судалгааны ажилд Улаанбаатар хотын гэр хороололд байрлах уурын зуухнаас ялгарах бохирдуулагч бодисын агууламжийн түвшинг тодорхойлж, яндангийн өндөр болон ашигласан жилээ шалтгаалах хамаарлыг тооилоо.

Tүлхүүр үгс: Уурын зуух, хийн бохирдол, азотын исэл, хүхрийн исэл;

\section{ОРШИЛ}

Улаанбаатар хотын төвлөрсөн дулаан хангамжийн системд холбогдоогүй захын хорооллуудад байгаа сургууль, цэцэрлэг, үйлдвэр, аж ахуйн нэгжийн барилга, байгууламжийн дулааны хангамжинд дотооддоо үйлдвэрлэсэн ба гадаадаас оруулж ирсэн хатуу түлшээр ажилладаг төрөл бүрийн маркийн янз бүрийн хүчин чадалтай нам даралтын зуухнууд өргөн хэрэглэж байгаа бөгөөд эдгээр зуухны хийц нь боловсронгуй бус нүүрсний бүтэц, шинж чанар, ширхэгийн хэмжээнд тохироогүйн улмаас дутуу шаталт ихтэй, нүүрс ихээхэн зарцуулж байгаагаас боловсруулж байгаа дулааны өөрийн өртөг их байгаагийн зэрэгцээ хүрээлэх буй орчныг бохирдуулж оршин суугчдын эрүүл мэндэд сөрөг нөлөөлөл учруулсаар байна [1].

Сүүлийн 20 гаруй жилийн турш зуухнуудад хийсэн туршилт, судалгааны үр дүнгээс харахад дулаан техникийн болон экологийн үзүүлэлтүүд улсын стандартын 
шаардлагыг хангахгүй байгаагийн зэрэгцээ ашигт үйлийн коэффициент (АҮК) нь үйлдвэрийн гаргасан утгаасаа 20-25\%-иар доогуур байгаa юм. Зуухны ашиглалтын үеийн бодит дулааны хүчин чадал төслийн чадлаасаа 1.5-2.0 дахин бага, өвлийн улиралд сүлжээний усны температур тооцоот утгандаa хүрэхгүй байгаагаас хэрэглэгчдийг шаардлагатай үзүүлэлт бүхий дулаанаар найдвартай хангаж чадахгүй байна [2].

Нүүрсээр ажилладаг эрчим хүчний блокуудын экологийн Үзүүлэлтүүдийг сайжруулах, орон нутгийн түлшийг өргөн хэмжээгээр ашиглахад шилжих бололцоог хангах зорилгоор нүүрсийг буцлах ба эргэх буцлах давхаргад шатаах технологи бий болсон байна. Агаарыг үечлэн өгч буцлах давхаргад шохойн чулууг нэмэн өгч нам температурт түлшийг шатаахад хүхэр ба азотын ислийн хаягдлыг нилээд хэмжээгээр бууруулж, тэдгээрийн концентрацийг цэвэрлэх систем хэрэглэхгүйгээр эрүүл ахуйн нормын хэмжээнд нь хүргэх

\section{МАТЕРИАЛ, АРГА ЗУЙ}

Улаанбаатар хотын захын хорооллуудад байрлах агаар бохирдуулагч эх үүсвэрүүдийн нэг болох уурын зуухнуудын утаанаас ялгарах хаягдал утааны $\mathrm{CO}, \mathrm{SO}_{2}$, $\mathrm{NO}_{x}$, НШҮТ гэсэн гол бохирдуулагчдын хэмжин харьцуулан судлахдаа дараах зорилтуудыг дэвшүүлэв. Үүнд:

Уурын зуухны шаталтын явцаас

Судалгааны арга, аргачлалыг дараах байдлаар бүдүүвчлэн үзүүлэв:

- Хээрийн судалгаанд ашигласан аргазүй

- Эх үүсвэрээс ялгарах бохирдуулагч бодисын тархалтын тооцооны аргазүй

Хээрийн судалгаанд ашигласан аргазүй. Хээрийн судалгаанд ашигласан багаж, тоног төхөөрөмжүүд: Утааны хийн анализаторHORIBA PG-250 нь $\mathrm{NO}_{x}, \mathrm{SO}_{2}, \mathrm{CO}, \mathrm{CO}_{2}$ болон $\mathrm{O}_{2}$ гэсэн 5 төрлийн найрлагыг нэгэн зэрэг хэмжих боломжтой, Автомат тоосны дээж авагч- MARUNI NDZ-5DK бололцоог олгодог байна [4].

Бага чадлын ус халаах зуухнуудын хийцийг боловсронгуй болгох, ашиглалтын нөхцлийг сайжруулах, үр ашгийг дээшлүүлэх нь өнөөгийн тулгамдсан асуудал болж байна. Үүнийг шийдвэрлэхийн тулд судлаачдын өмнө бага чадлын зуухны хийцийг байгаль орчинд хор, хөнөөл багатай болгох, үр ашгийг дээшлүүлэх, ашиглалтын нөхцлийг сайжруулах чиглэлээр судалгааны ажил хийгдэх шаардлага гарч байгаа юм. Судалгаандаа тулгуурлан байгаль орчинд ээлтэй зуухны шинэ хийцийг зохион бүтээж туршиж хэрэгжүүлсэн байна [3].

Хятад болон Монгол улсад үйлдвэрлэсэн зуухыг харьцуулан АҮК-ийг тодорхойлсон. Эндээс 0.2...1.4МВт хүчин чадалтай НР-18, БЗУИ-100 маягийн зуухны АҮК бага 40$50 \%$, Хятад маягийн зуух АҮК $60 \%$ байгаа, Монсан ХХК-ны Монзуухны АYК 75-85\% байгаa нь бусад зуухнуудтай харьцуулахад түлшний зарцуулалт ба бохирдуулагч бодисын ялгаруулалт бага байна [5].

ялгарч буй агаар бохирдуулагч зарим хий болох $\mathrm{CO}, \mathrm{SO}_{2}, \mathrm{NO}_{x}$, НШҮТ-н агуулгыг харьцуулах, үүнд ашигласан хугацаа болон яндангийн өндөр нөлөөлж буй эсэх

Уурын зуухны шаталтын явцаас ялгарах агаарын түгээмэл бохирдуулагчийн орон зайн тархалтын тооцоог хийх зэрэг болно. нь утааны хийн хурд тохируулан соруулах зарчмаар тоосны дээж авах аргачлалыг автомажуулсан төхөөрөмж юм.

Агаарын бохирдльн математик загварчлалын арга зуй (Гауссын загварчлал). Хаягдлаас хамаарсан агаарын бохирдлыг тооцох бүхий л компьютерын программын үндэс нь Гауссын тархалтын муруй байдаг. Энгийн Гауссын тархалтын загварыг шугаман эх үүсвэр болон талбайн эх үүсвэр болгон өөрчилж бас болно.

Гауссын загвар нь концентрацийн тархалт нь хэвийн байна гэж үзнэ. Гауссын 
цэгэн эх үүсвэрийн тархалт нь эх үүсвэрийн хүчин чадал, салхины хурд, яндангийн өндөр, орчны нөхцөл зэргээс хамаарна. Анализ хийхэд дараах таамаглалыг дэвшүүлсэн байна. Үүнд:

- Салхины хурд аль ч цаг болон өндөрт тогтмол.

- Бохирдол нь багасахгүй, газар шингэхгүй, химийн урвалд орохгүй.
- Газар нь ерөнхийдөө талархаг.

Гурван хэмжээст Гауссын загвар нь яндан дээр тулгуурлагдах ба зай нь х-ээр өгөгсдөн, босоо зай нь у-ээр өгөгдсөн ба өндрийг z-ээр авчээ. Бидний гол анхаарах ёстой зүйл бол хүлээн авагчид (зөвхөн хүн болон экосистем) газар байгаа нөхцөлд Гауссын тэгшитгэлийг зөвхөн $\mathrm{z}=0$ байхад л ашиглаж болно.

$$
C(x, y)=\frac{Q}{\pi u \sigma_{y} \sigma_{z}}\left(\exp \frac{-H^{2}}{2 \sigma_{z}^{2}}\right)\left(\exp \frac{-y^{2}}{2 \sigma_{y}^{2}}\right)
$$

\footnotetext{
$\mathrm{C}(\mathrm{x}, \mathrm{y})$ - цэгийн газрын гадарга дээрхи агууламж, мг/м3

Q - бохирдлын ялгаруулалтын хэмжээ, г/с

Н - яндангийн өндөр, м

u - яндангийн хийн хурд, м/с

$\sigma_{y}$ - хэвтээ тархалтын коэффициент (стандарт хазайлт), м

$\sigma_{z}$ - босоо тархалтын коэффициент (стандарт хазайлт), м
}

Яндангийн өндөр нэмэгдэх тусам газар дээрхи концентраци бага байдаг гэхдээ хамаарал нь шугаман биш юм. Хэдий Гаусс нь онол болон тоон мэдээлэл дээр тулгуурладаг хэдий ч загварын хувьд боловсронгуй биш юм. Загвар дээр тулгуурлан хийсэн таамаглалын үнэмшилтэй байдал нь 50\% дотор л байх юм. Энэхүу тодорхойгүй байдлыг үл

\section{ҮР ДҮН}

Судалгааны ажлын үр дүнг хээрийн хэмжилт, судалгааны үр дүн, агаарын бохирдлын математик загварчлалын үр дүн гэж авч үзлээ.

Хээрийн судалгааны үр дүн. Хээрийн судалгаагаар уурын зуухны өндөр, амсарын диаметр, эх үүсвэрийн байршил, ялгаралтын хэмжээ /түгээмэл бохирдуулагч тус бүрээр/, хийн температур, хийн урсгалын хурд зэрэг үзүүлэлтийг гаргасан. Улаанбаатар хотын гэр хороололд байрлах сургууль, цэцэрлэгийн дулааныг хангадаг томоохон 20-н уурын зууханд хэмжилт судалгааг хайхран энэхүу загвар нь дэлхий даяар хүлээн зөвшөөрөгдсөн учраас чухал байдаг [6].

Энэхүу судалгаанд бохирдлын ялгаралтанд үйлдвэрлэсэн он болон, яндангийн өндрийн хэрхэн нөлөөлж буйг судлах үүднээс ялгаа бүхий 20-н зуухыг түүвэрлэн авч судалгаанд хамрууллаа.

хийлээ (Зураг 1). Судалгаанд хамрагдсан нийт зуухны хүхэрлэг хийн агууламжаар $85 \%$ нь стандарт хэмжээнээс хэтэрсэн байгаа бөгөөд Үүнээс 30\% нь стандартаас хэмжээнээс 1.8-2.1 дахин хэтэрсэн байгаа ба Монголд үйлдвэрлэсэн НР-18 зуухны хүхэрлэг хий өндөр агууламжтай байна. Мөн Монголд үйлдвэрлэсэн MWB төрлийн зуухны агууламж стандарт хэмжээнээс 1.8 дахин, Монголд үйлдвэрлэсэн BNEB зуухны хийн агуулга стандарт хэмжээнээс 1.75 дахин ихэссэн байгаа нь харагдаж байна (Зураг 2). 


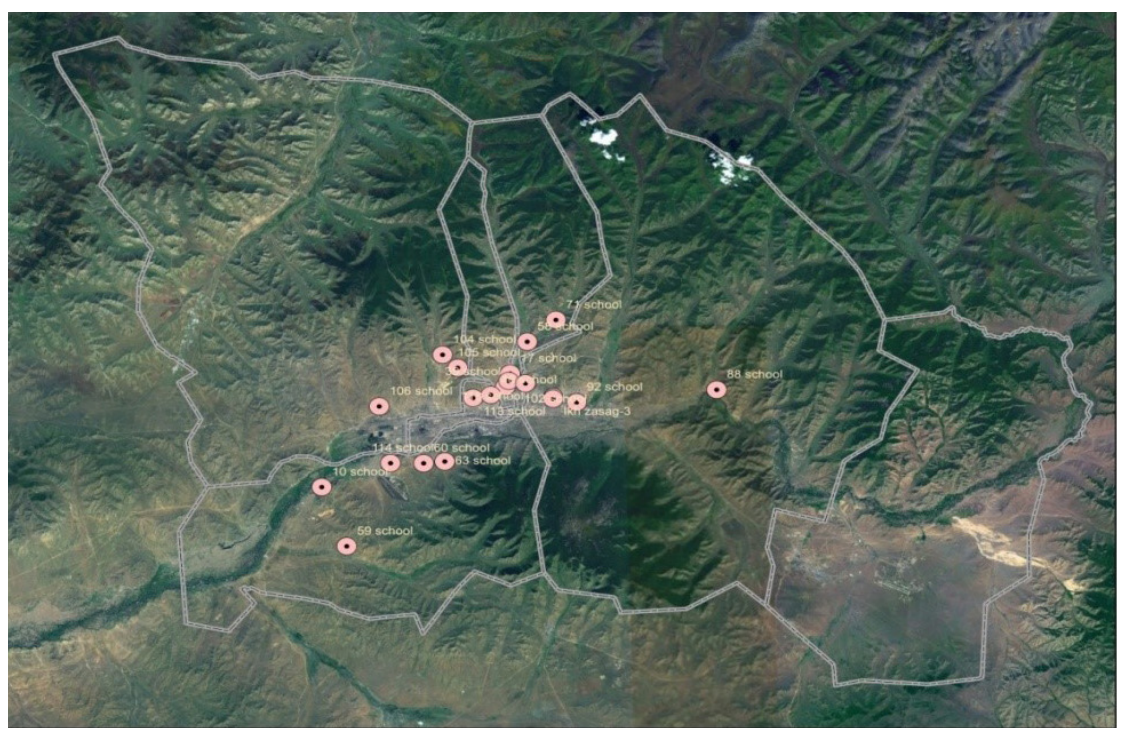

Зураг 1. Судалгааны иээгийн байршил

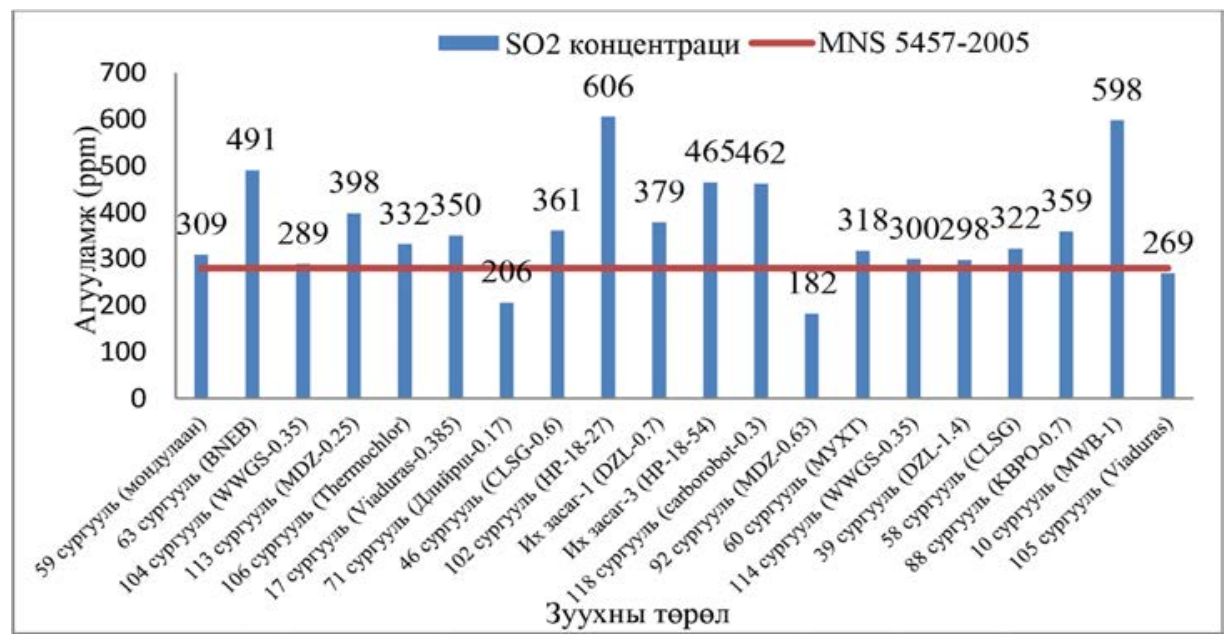

Зураг 2. Уурын зуухнаас ялгарах хүхэрлэг хийн агууламж

Нүүрстөрөгчийн дутуу исэл буюу угаарын хийн (CO) агууламжаар мөн л 85\% орчим нь стандарт хэмжээнээс хэтэрсэн байна. Хятад улсад үйлдвэрлэсэн CLSG, WWGS, Монгол улсад үйлдвэрлэсэн MWB төрлийн зуухнуудын агууламж стандарт хэмжээнээс 2-2.6 дахин ихэссэн. Нунтаг ихээр агуулсан нүүрсний шаталтын явцад нүүрсний давхарга нягтаршиж агаар нэвчихэд саад учруулж ноцолт, асалт сунжран удааширснаар шаталт муу явагдаж галын хотол дахь температур нам болсноор нүүрстөрөгчийн дутуу исэл их үүсдэг. Ашиглалтын практикт хүйтэн галын хотолд буюу бага ачааллаар ажиллаж байгаа тохиолдолд галын хотолд их нүүрс оруулж дэгдэмхий бодис ялгаралтын үеийг уртасгаснаар дутуу шаталтаар үүсэх хаягдлыг эрчимтэй нэмэгдүүлдэг (Зураг 3). 


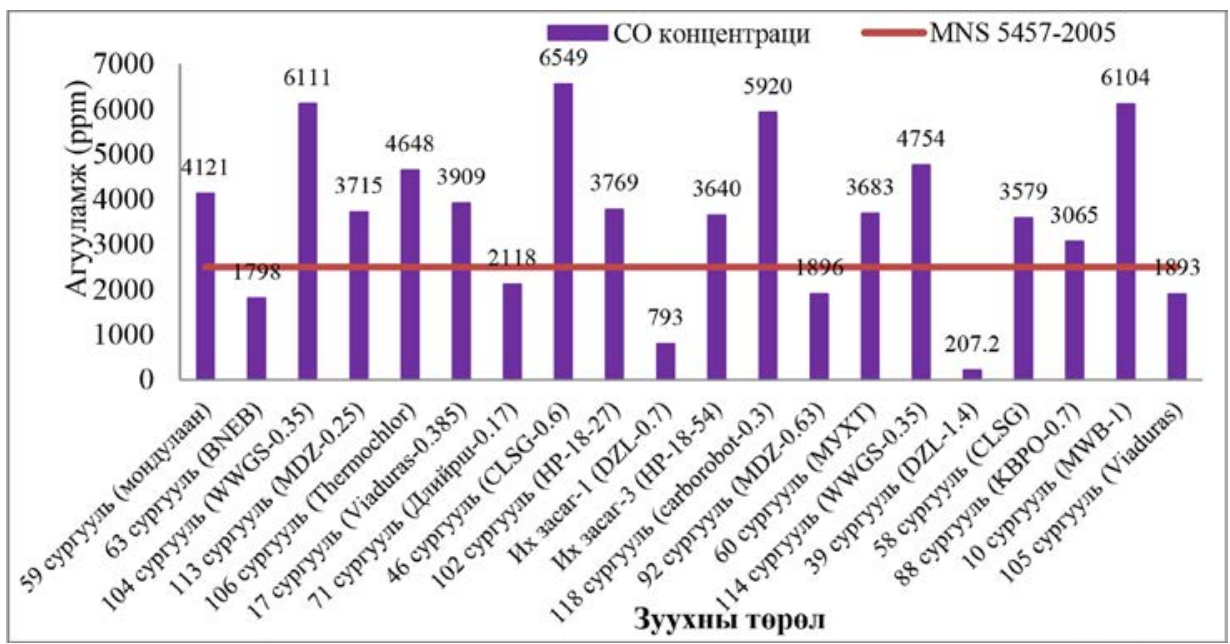

Зураг 3. Уурын зуухнаас ялгарч буй нүҮрстөрөгчийн дутуу ислийн (СО) агууламж

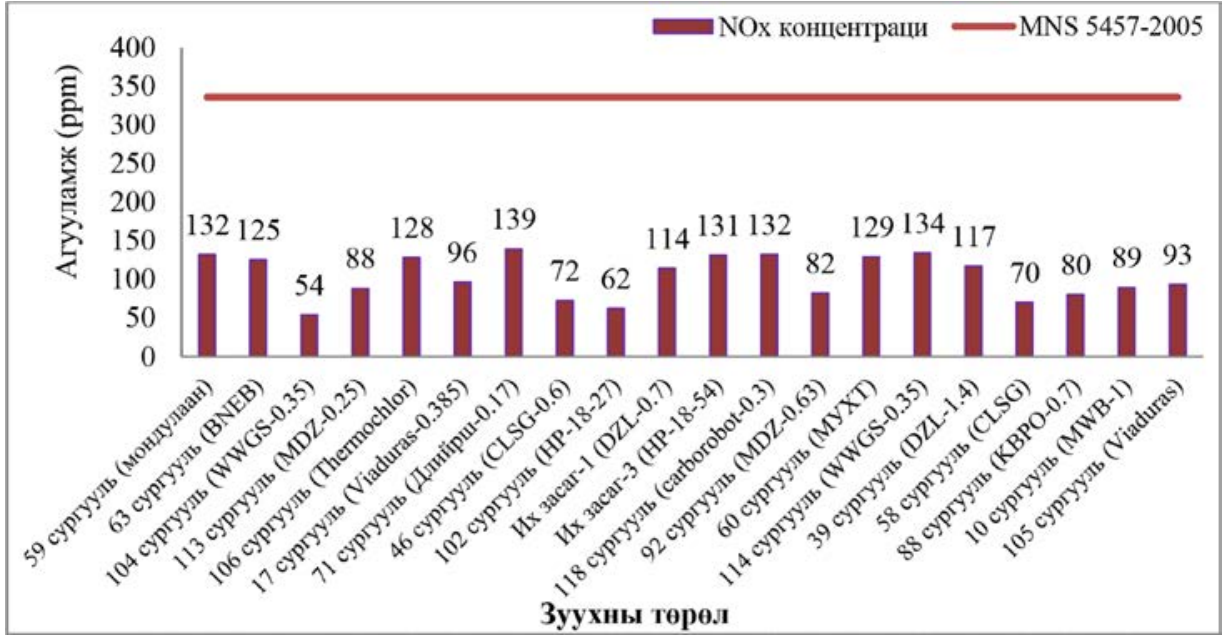

Зураг 4. Уурын зуухнаас ялгарч буй азотын ислүYд (NO,)-ийн агууламж

Доорх графикт зуухны шаталтаас үүсэх азотын ислийн агууламж стандарт хэмжээнээс хэтрээгүй байна. Энэ нэг талаасаа галын хотлын температур бага байх үед азотын ислүүд бага ялгардаг (Зураг 4).

НШҮТоосны агууламж нийт зуухнуудын $40 \%$ нь стандарт хэмжээнээс хэтэрсэн үзүүлэлттэй байна. Үлээх салхилууртай цилиндр хэлбэрийн CLSG0.25 төрлийн зуухнуудын НШҮТоосны агууламж өндөр байдаг байна. Энэ нь галын хотлын дээд талд яндан холбогдсон байдаг бөгөөд утааны хий дамжих суваг богино байдаг байна. Харин нүүрсний дамжлага конверттой, утааны хийн усан шүүгчтэй DZL гэх мэт төрлийн зуухнуудын НШҮТоосны агууламжийн ялгаруулалт багатай юм (Зураг 5).

Зуух бүрд харилцан адилгүй өөр өөр хэмжээтэй түлш хэрэглэдэг бөгөөд үүнийг ижил түвшинд харьцуулахын тулд 1тн нүүрсийг жишиг үзүүлэлт болгон тооцож агууламжуудыг харьцуулсан болно. 


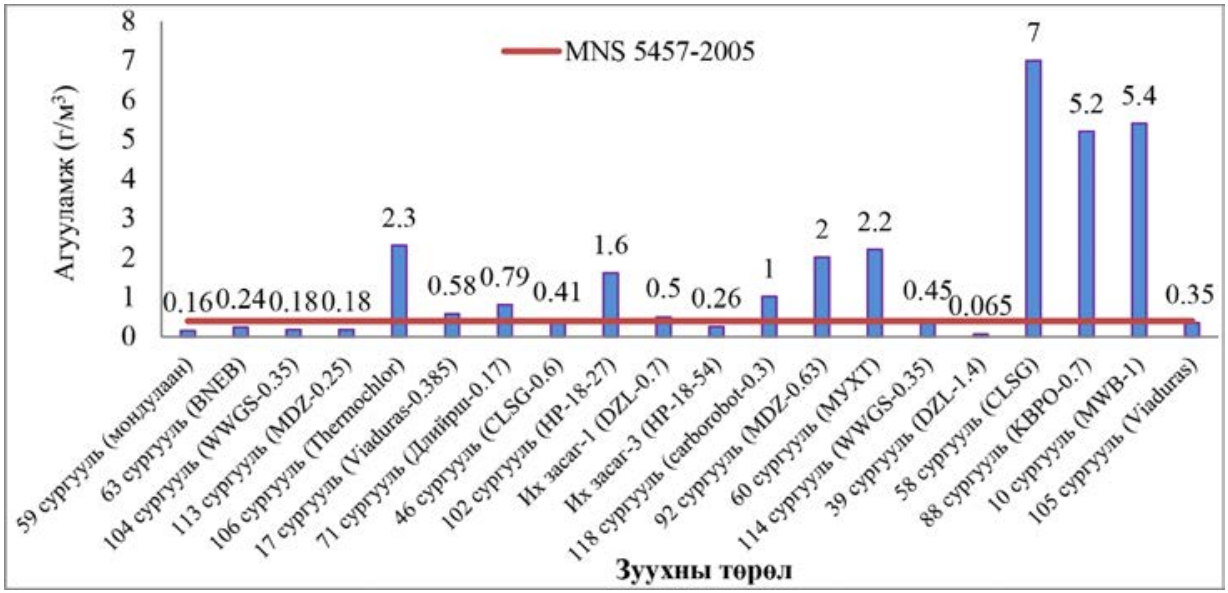

Зураг 5. Уурын зуухнаас ялгарч буй дэгдэмхий үнсний агууламж

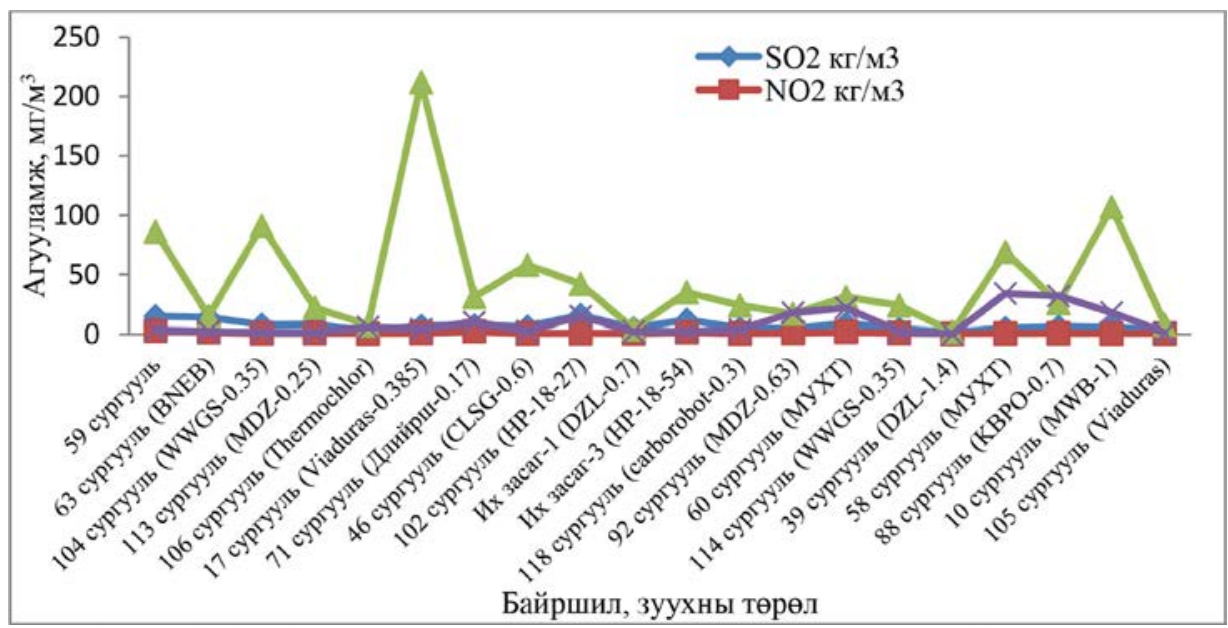

Зураг 6. 1тн нүүрс шатаахад ялгарах бохирдуулагч хийн бодисын хэмжээ

1тн нүурс шатаахад ялгарах бохирдуулагч бодисын агууламжийг дээрх графикаас харахад азотын исэл $\left(\mathrm{NO}_{x}\right)$ болон хүхэрлэг хийн $\left(\mathrm{SO}_{2}\right)$ агууламж зуухны төрлөөс хамаарахгүй байна. Харин НШҮТоос бага зэргийн хэлбэлзэлтэй, нүүрстөрөгчийн дутуу ислийн агууламж нилээд их хэлбэлзэлтэй байгаа харагдаж байна. 17-р сургууль дээр байрлах виадурас-0.385 төрлийн зуухны нүүрстөрөгчийн дутуу ислийн агууламж

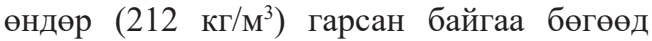
энэ зуух нь 2005 онд суурьлагдсан зуух юм. Суурьлагдсанаас хойш ямар нэгэн техникийн шинэчлэл засвар хийгдээгүй

нилээд хуучирсан зуух байсан (Зураг 6).

Судалгаанд хамрагдсан нийт зуухны 45\% нь 6-8 жил ашигласан, 30\% нь 4-5 жил ашигласан зуухнууд байна. 25\% нь 2-3 жилийн өмнө суурьлуулсан байна.

Уурын зуухны хийцийг боловсронгуй болгох, үр ашгийг нь дээшлүүлэх талаар төдийлөн анхаарал тавихгүй, зөвхөн хэрэглэгчдийг хөлдөөлгүй дулаанаар хангах шаардлагын үүднээс ажиллаж байсны улмаас хийц нь хоцрогдож тухайн орон нутгийн нүүрсний бүтэц, шинж чанарт тохирохгүй байгаагаас шалтгаалан түлш ихээр зарцуулж, ашигт ажиллагааны 
түвшин доогуур, бохирдуулагч бодис ихээр ялгаруулах шалтгаан болоод байна.

Зуухнуудын ашигласан жил болон 1тн нүүрс шатаахад ялгарах бохирдуулагч бодисуудын агууламжтай харьцуулан харуулбал: виадурас-0.385 зуухнаас ялгарах нүүрсхүчлийн дутуу ислийн агууламж нилээд их $\left(212 \kappa г / \mathbf{M}^{3}\right)$ байгаа нь уг зуухыг 8 жил ашиглаж ашиглалтын хугацаанд техникийн шинэчлэл хийгдээгүй байсантай холбоотой юм. Зарим төрлийн зуухыг 5-6 жил ашигласан байгаа ч ялгарах бохирдуулагч бодисын агууламж нь бага үзүүлэлттэй байгаа нь харагдаж байна. Энэ нь зуухнуудад техник засварын, шинэчлэлийг хийж засвар хийсэн байж болох талтай (Зураг 7).

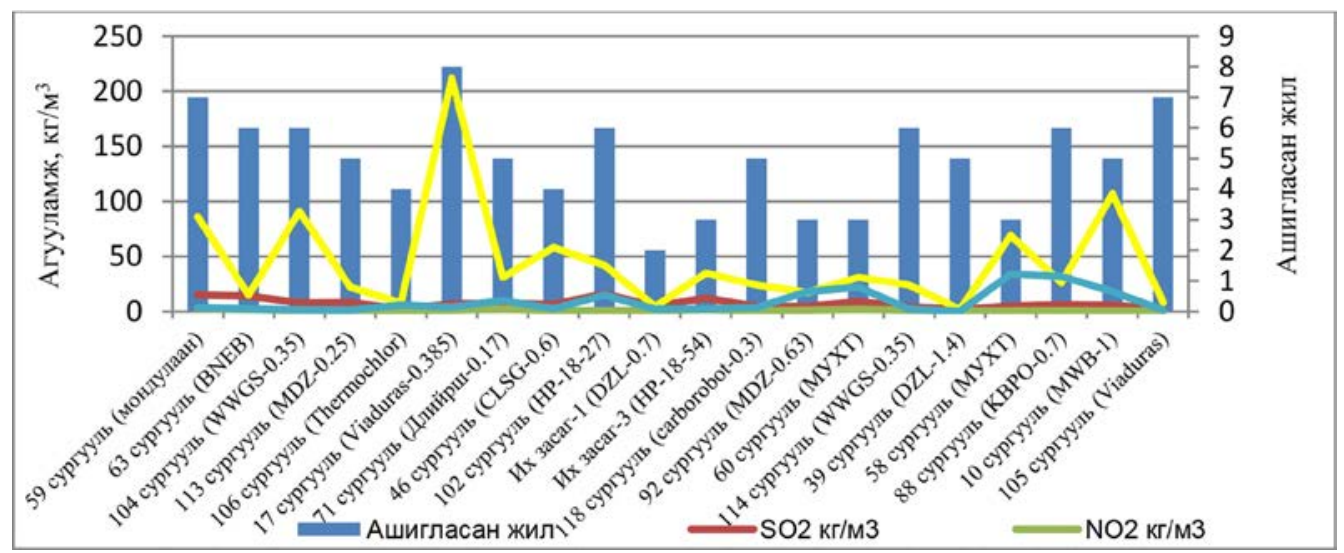

Зураг 7. Зуухнуудын ашигласан жил болон бодисуудын агууламжийн давхцал

\section{Агаарын бохирдлын математик загварчлалын үр дүн}

Судалгаанд хамрагдсан нийт уурын зуухны шаталтын явцад утаанаас хоногт ялгарах гол бохирдуулагч хийн агаар орчин дахь тархалтыг математик загварчлалыг "Screening Air Dispersion Model (SCREEN 3)" программаар тооцож гаргасан бөгөөд бүх эх үүсвэрүүд өндөрлөг бус газар нутгийн хувьд ерөнхийдөө талархаг гэсэн таамаглалаар тооцсон болно. Доорх загварчлалын бодолтын утга нь 100м тутамд гэсэн нөхцлөөр хийгдсэн бөгөөд 1м тутмын нарийвчилсан утгыг дүрслээгүй. Тооцооллын дүнгээс харвал бохирдуулагч хийн хамгийн дээд агууламж нь BNEB-0.23 зуухны утаанаас ялгарах нүүрстөрөгчийн дутуу исэл нь $399.4 \mathrm{Mr} / \mathrm{M}^{3}$ агууламжтай байгаa бөгөөд мөн Мондулаан-0.063 зуухных 360.5 мг/м ${ }^{3}$ байгаа нь харагдаж байгаа ба эх үүсвэрээс 50м зайд байна. Зургаас харахад бохирдуулагч хийн агууламж 100м-т хамгийн өндөр байгаа бөгөөд 500м-ээс эхлэн бохирдуулагч хийн агууламж буурч байгаа нь харагдаж байна (Зураг 8).

Мөн BNEB-0.23 зуухны утаанаас ялгарах хүхэрлэг хийн агууламж 139 мг/м², мондулаан-0.23 зуухны утаанаас ялгарах хүүхэрлэг хий 101.4 мг/м ${ }^{3}$ агууламжтай байгаа бөгөөд эх үүсвэрээс 50м зайд байна. Зургаас харахад бохирдуулагч хийн агууламж 100м-т хамгийн өндөр байгаа бөгөөд 400м-ээс эхлэн бохирдуулагч хийн агууламж буурч байгаа нь харагдаж байна (Зураг 9).

Зургаaс харахад BNEB-0.23 зуухны утаанаас ялгарах азотын ислийн агууламж $97.32 \mathrm{мг} / \mathrm{M}^{3}, \quad$ мондулаан- 0.23 зуухны утаанаас ялгарах азотын ислийн агууламж 81.55 мг/м³ байгаа ба бусад зуухнуудаас өндөр агууламжтай байгаa нь харагдаж байна. Бусад зуухнуудын хувьд азотын ислийн агууламж 100м-т харьцангуй өндөр агууламжтай байснаa 200м-ээс багасаж байна (Зураг 10). 


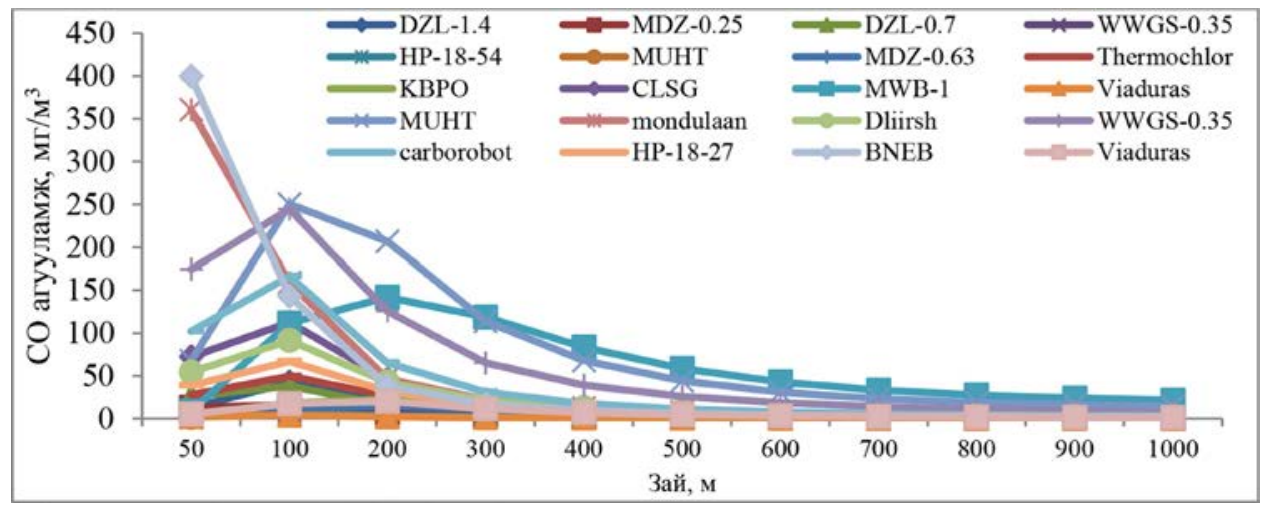

Зураг 8. Уурын зуухны утаанаас ялгарах нүҮрстөрөгчийн дутуу ислийн (СО) тархалт

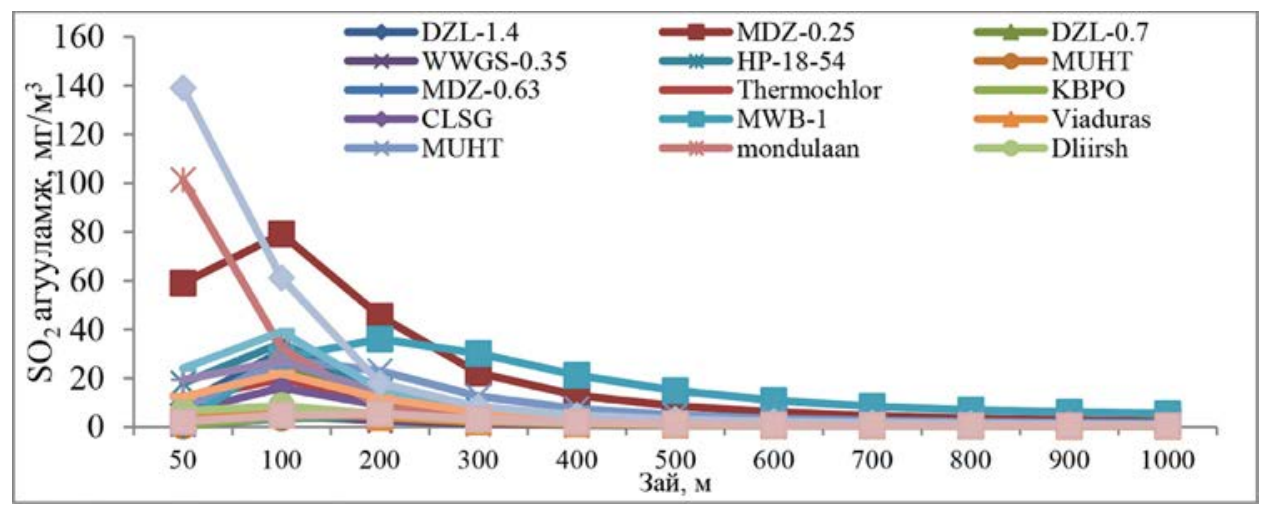

Зураг 9. Уурын зуухны утаанаас ялгарах хүхэрлэг хийн $\left(\mathrm{SO}_{2}\right)$ тархалт

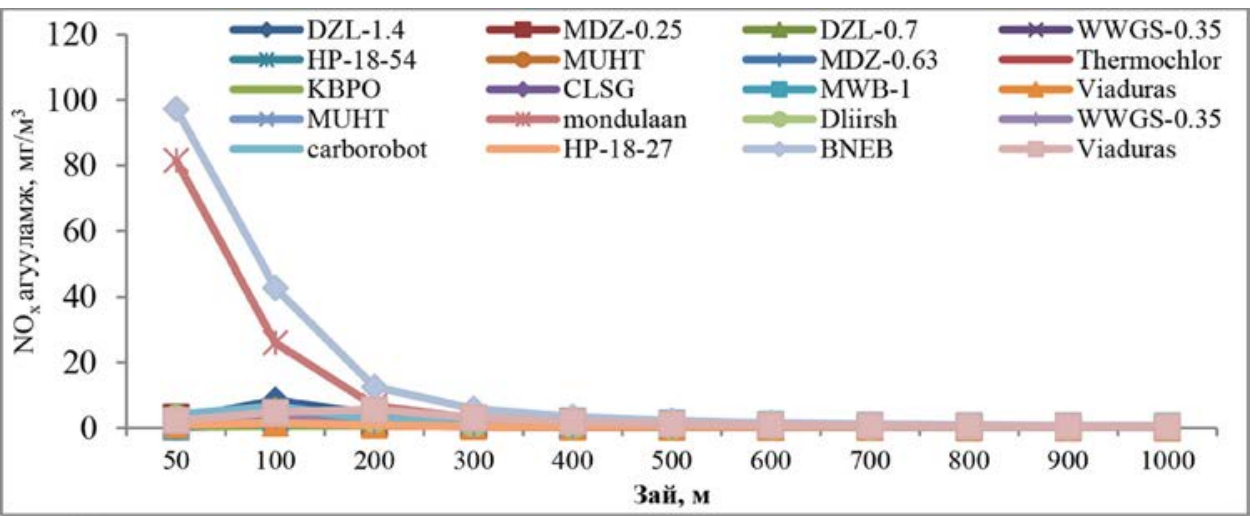

Зураг 10. Уурын зуухны утаанаас ялгарах азотын ислийн $\left(N O_{x}\right)$ зайн тархалт

Мондулаан-0.063 зуухны утаатай хамт ялгарах дэгдэмхий үнсний агууламж 116.5 $\mathrm{M \Gamma} / \mathrm{M}^{3}$, харин BNEB-0.23 зуухны утаанаас ялгарах дэгдэмхий үнсний агууламж 299.5 мг/м³ байна. Зургаас харахад бохирдуулагч хийн агууламж $100 \mathrm{M}-\mathrm{T}$ хамгийн өндөр байгаа бөгөөд 400м-ээс эхлэн бохирдуулагч хийн агууламж буурсан. Бохирдуулагч хийн агууламж 100м-т хамгийн өндөр байгаа бөгөөд 400м-ээс эхлэн бохирдуулагч хийн агууламж буурч байна (Зураг 11). 


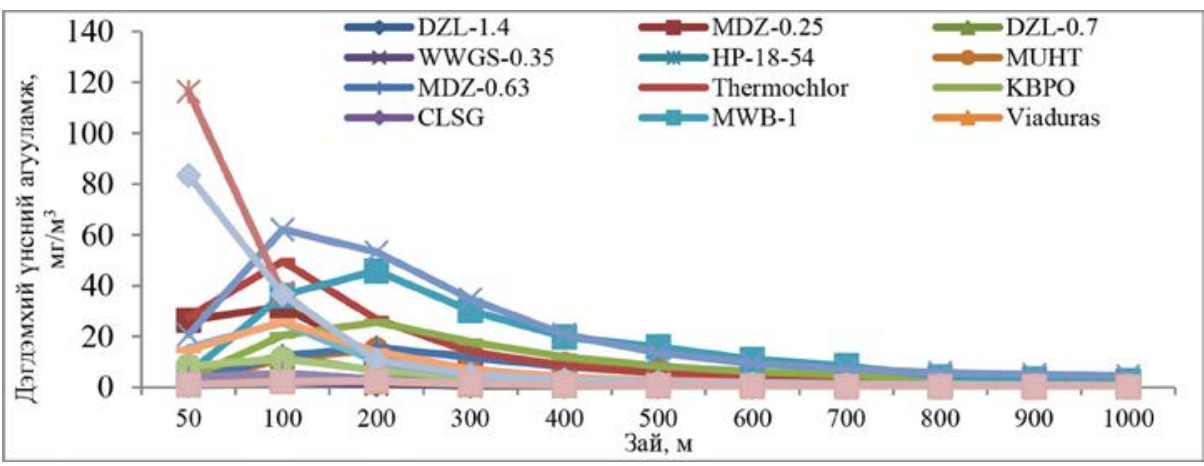

Зураг 11. Уурын зуухны утаанаас ялгарах дэгдэмхий үнсний тархалт

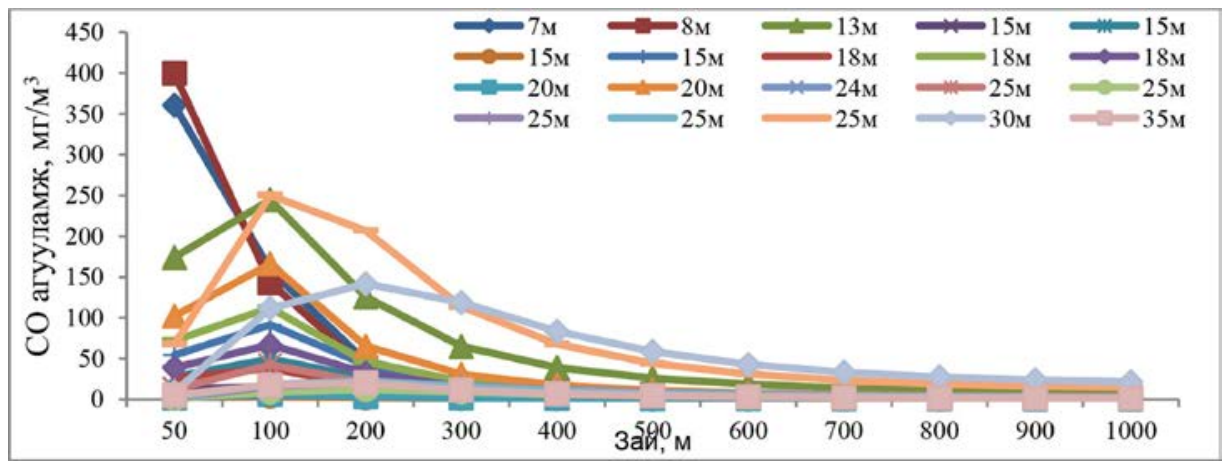

Зураг 12. Уурын зуухнаас ялгарах нүүрстөрөгчийн дутуу исэл болон яндангийн өндрийн хамаарал

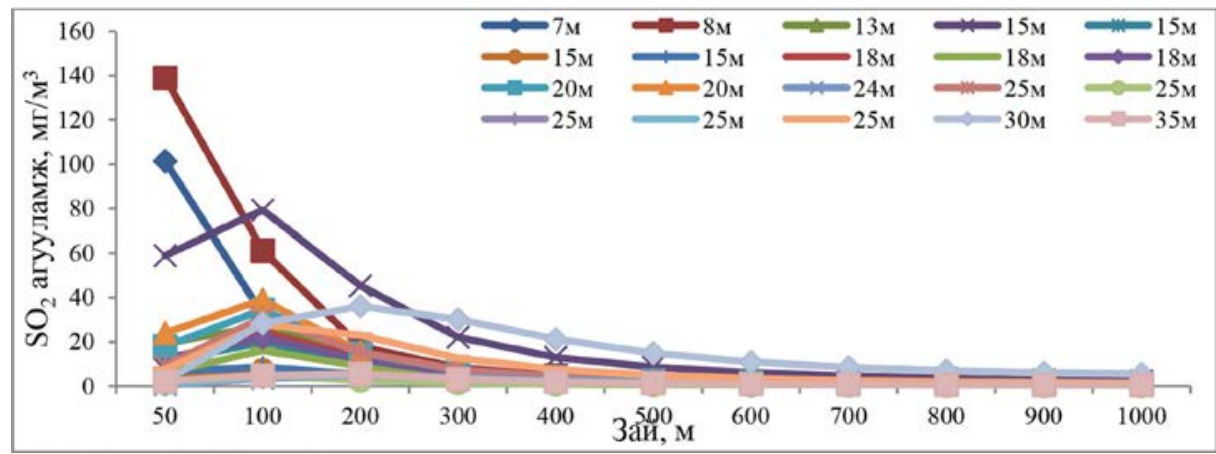

Зураг 13.Уурын зуухнаас ялгарах хүхэрлэг хийн агууламж болон яндангийн өндрийн хамаарал

Бохирдуулагч хийн агууламжийг яндангийн өндөрөөс хамааруулан авч үзвэл: 7 м өндөр яндантай зуух, 8м яндангийн өндөртэй зуухны агууламж өндөр байна. Зургаас харахад яндангийн өндөр нэмэгдэх тусам нүүрстөрөгчийн дутуу ислийн агууламж ерөнхийдөө буурч байгаа юм. Гэхдээ 25м яндантай зуухны агууламж их байгаа нь бодисын агууламжинд дан ганц яндангийн өндөр хамаарч байна гэж үзэхгүй бөгөөд цаг уурын бусад хүчин зүйл нөлөөлж байна (Зураг 12).

7 м өндөр яндантай зуух, 8м яндангийн өндөртэй зуухны агууламж өндөр байна. Зургаас харахад яндангийн өндөр нэмэгдэх тусам хүхэрлэг хийн агууламж ерөнхийдөө буурсан (Зураг 13).

7 м өндөр яндантай зуух, 8м яндангийн 
өндөртэй зуухны агууламж өндөр байна. Бусад зуухнуудын хувьд азотын давхар ислийн агууламж багассан (Зураг 14).

$7 \mathrm{M}$ өндөр яндантай төрлийн зуух, 8м яндангийн өндөртэй зуухны утаанаас ялгарч буй дэгдэмхий үнсний агууламж өндөр байна. 25 м өндөр яндантай зуухны агууламж бага зэрэг их байгаа нь бодисын агууламжинд дан ганц яндангийн өндөр биш бусад цаг уурын нөхцлүүд хамаардагтай холбоотой юм (Зураг 15).

Мөн 1тн нүүрс шатаахад ялгарах бохирдуулагч хийн агууламжийг уурын зуухны яндангийн өндрөөс хамаарах хамаарлыг корреляцын коэффициентоор тооцож үзлээ (Зураг 16)

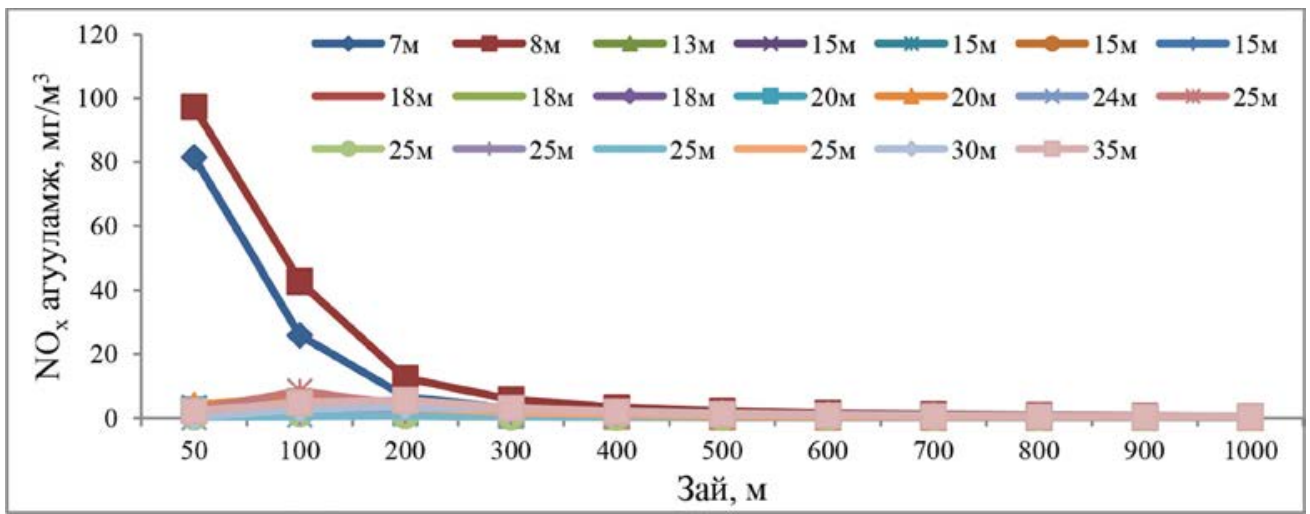

Зураг 14. Уурын зуухнаас ялгарч буй азотын ислүҮдийн агууламж болон яндангийн өндрийн хамаарал

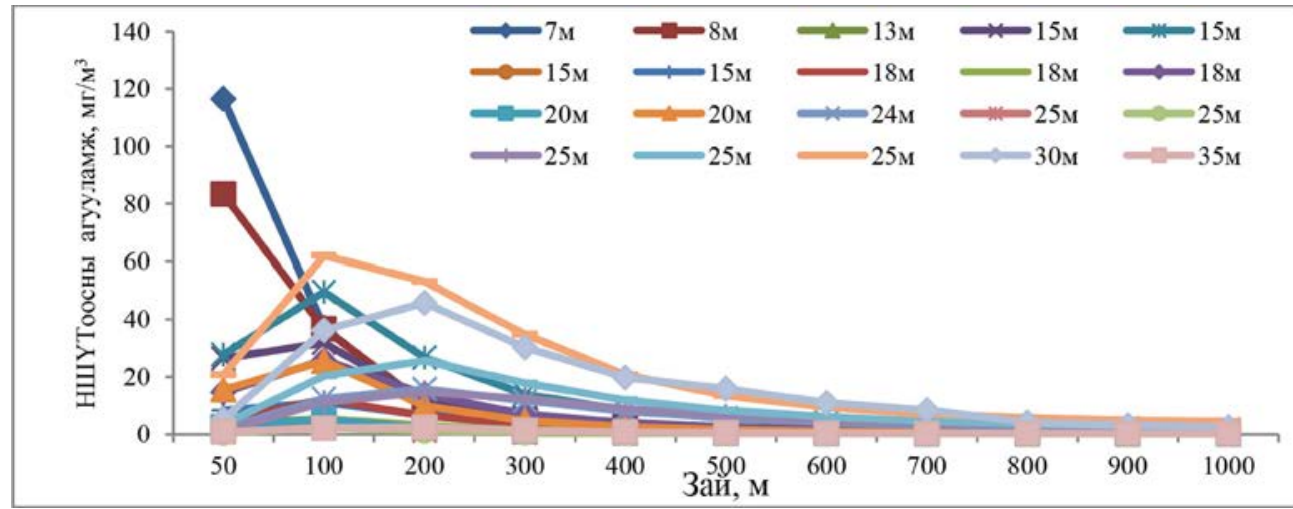

Зураг 15. Уурын зуухнаас ялгарч буй дэгдэмхий үнсний агууламж болон яндангийн өндрийн хамаарал

Уурын зуухны яндангийн өндөр болон нүүрстөрөгчийн дутуу исэл (СО) -ийн агууламжийн корреляцын хамаарал нь $\mathrm{r}$ $=-0.80873$ буюу хүчтэй урвуу хамааралтай байгаа бөгөөд хүхрийн давхар ислийн $\left(\mathrm{SO}_{2}\right)$ агууламжийн хамаарал $\mathrm{r}=-0.75922$ буюу хүчтэй урвуу, азотын давхар ислүүдийн агууламжуудын хамаарал $\left(\mathrm{NO}_{\mathrm{x}}\right) \mathrm{r}=-0.69252$ хүчтэй урвуу хамааралтай байна. Мөн уурын зуухны яндангийн өндөр болон дэгдэмхий үнсний агууламжийн корреляцын хамаарал $\mathrm{r}=-0.72245$ буюу хүчтэй урвуу хамааралтай байна. Энэ хамаарлаас харахад яндангийн өндөр нэмэгдэхэд бохирдуулагч хийн агууламж буурч байна. 


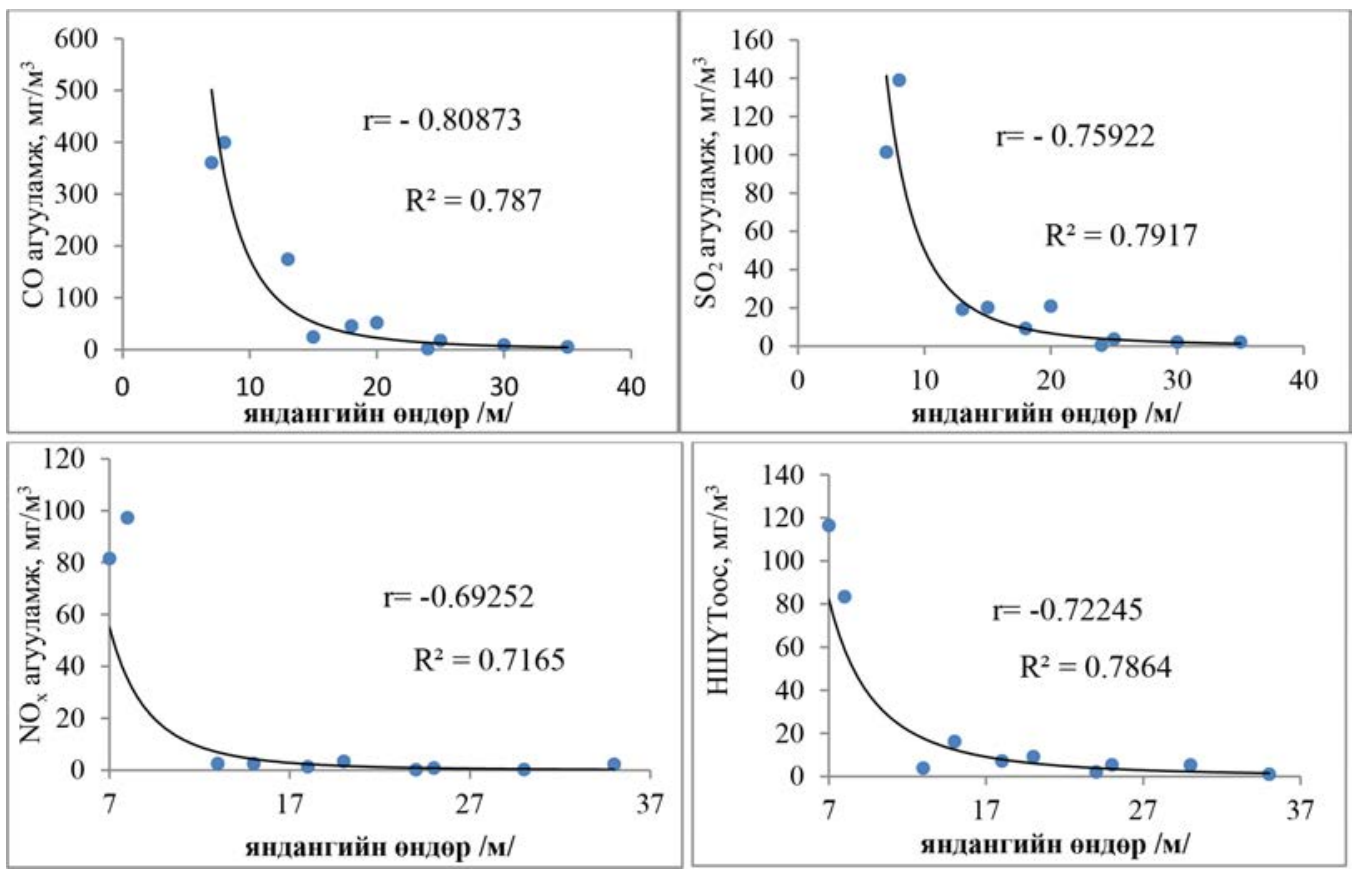

Зураг 16. Яндангийн өндрөөс бохирдуулагч хийн хамаарах хамаарал

\section{ДҮГНЭЛТ}

Судалгааны ажлын үр дүнд дараах дүгнэлтүүдийг хийж байна. Үүнд:

1. Нийт хэмжилт хийгдсэн зуухны хүхэрлэг хий, нүүрстөрөгчийн дутуу ислийн $85 \%$ нь стандарт хэмжээнээс давсан үзүүлэлтэй байгаа бөгөөд Монгол улсад үйлдвэрлэсэн МWB, HP-1.8, BNEB төрлийн зуухнуудын шаталтын явцад үүсэх бохирдуулагч хий өндөр агууламжтай гарсан байна.

2. Яндангаaс гарах утааны бохирдуулагч хийн агууламжийн тархалт 100 м зайнаас эхлэн ихсэж байгаa ба ерөнхийдөө 500м-ээс эхлэн стандарт хэмжээ рүY буурч байна. BNEB болон Мондулаан зуухнуудын шаталтын явцад үүсэх бохирдуулагч хийн агууламж 50м зайнд өндөр агууламжтай байгаа ба энэ зуухнуудын яндангийн өндөр 7-8м юм.

3. Зуухнуудын ашиглалтын жил нь янз бүр байгаа ба олон жил (8-аас дээш жил) ашигласан зуухнуудын шаталтын явцад Үүсэх бохирдуулагч бодисын агууламж өндөр гарсан ба хамаарлыг нь тооцвол: $\mathrm{CO}$ агууламж нь мэдэгдэхүйц шууд, $\mathrm{SO}_{2}, \mathrm{NO}_{x}$ агууламж сул шууд хамааралтай байна.

\section{НОМ ЗYЙ}

[1] Цэен-Ойдов Ж, (1998) “Бага чадлын ус халаагуурын зуухны хийцийг боловсронгуй болгох нь” ТИС-ийн эрдэм шинжилгээний бичиг, 3, 62-71

[2] Түмэннаст Ё, (2012) "Уурын зуухны шаталтын явиад агаарт ҮҮсэх бохирдуулагч бодис, хүлэмжийн хийн судалгаа” ШУТИС-ЭШБ, 45-58

[3] Бат-Эрдэнэ Б, (2013) “Бага чадлын уурын зуухны эдийн засаг, экологийн үр ашгийг дээшлҮҮлэх судалгаа" ШУТИС, ЭХИС, Судалгааны тайлан, 101-118

[4] Цэен-Ойдов Ж, (2002) “Орон нутгийн дулаан хангамжийн эх үүсгуҮрийг

$$
-51-
$$


боловсронгуй болгох нь ” эрдэм шинжсилгээний бүтээл, 7, 131-145

[5] Цэен-Ойдов Ж, Түмэнбаяр А, (2005) “Уурын зуухны агаар мандалд ҮзүҮлэх нөлөөллийн судалгаа" диссертаии

[6] Gilbert M. Masters, (2003) "Introduction to Environmental Engineering and Science" 


\title{
RESEARCH OF POISONOUS FUMES EMISSION FROM COMBUSTION IN THE STEAM BOILERS
}

\author{
Sonomdagva Ch, Erdemtsetseg Sh \\ Department of Environment and Forest Engineering \\ School of Engineering and Applied Science, NUM \\ E-mail: ch_sonomdagva@num.edu.mn
}

Determined following objectives while comparatively studied measuring main poisonous fumes such as volatile ash, $\mathrm{CO}, \mathrm{SO} 2, \mathrm{NOx}$ which are released in the fume from steam boilers, which are one of the air polluting sources, located in the suburb areas of Ulaanbaatar city.

At the heart of most every computer program that attempts to relate emissions to air quality is the assumption that the time-averaged pollutant concentration down-wind from a source can be modelled using a normal, or Gaussian, distribution curve. The basic Gaussian dispersion model applies to a single point source, such as a smokestack, but it can be modified to account for line sources or area sources.

Steppe measurements, practical value of the research and outcomes of the mathematical modelling are all being considered as the practical value of the research. Through Steppe research, determined indicators such as height of the steam boiler, diameter of the edge, location of the source, amount of fumes emission, gas temperature and gas stream speed.

The $85 \%$ of the steam boilers involved in the research were releasing sulphurous gas which has more or less exceeded standards and $30 \%$ of those were exceeding the standards by $1.8-2.1$ times. Smoke, emitted from steam boiler that is produced in Mongolia contained sulphurous gas of high content (606 ppm).

This research, determined content of poisonous fumes emitted from steam boilers located in the ger districts of Ulaanbaatar city and calculated the poisonous fumes content in relation with the duration of steam boilers exploitation and the height of the exhaust pipe.

Keywords: Steam boilers, gas pollution, nitrogen oxide and sulfar oxide; 